\title{
Analiza pooperacyjnego leczenia protetycznego pacjentów w latach 2002-2015
}

\author{
Analysis of the postoperative prosthetic treatment of patients \\ in the years 2002-2015
}

Katedra i Zakład Protetyki Stomatologicznej, Uniwersytet Medyczny im. Piastów Śląskich we Wrocławiu

DOI: http://dx.doi.org/10.20883/df.2016.4

\begin{abstract}
Streszczenie
Wstęp. Leczenie protetyczne po zabiegach operacyjnych w zakresie szczęki i żuchwy ma za zadanie odtworzyć okluzję, przywrócić funkcję żucia, poprawić mowę i wygląd zewnętrzny pacjenta oraz uszczelnić i odciążyć obrzeże operowane.

Cel. Analiza protez pooperacyjnych szczęki i żuchwy u pacjentów leczonych w latach 2002-2015 w Zakładzie Protetyki Stomatologicznej Uniwersytetu Medycznego im. Piastów Śląskich we Wrocławiu.

Materiał i metody. Materiał do badań stanowiło 35 pacjentów, w tym 17 kobiet i 18 mężczyzn, w wieku od 24 do 91 lat. Leczonych podzielono ze względu na wiek, płeć, rozpoznanie, liczbę i rodzaj wykonanych protez pooperacyjnych, miejsce zamieszkania pacjentów, wykonywany zawód, rodzaj miękkiego materiału zastosowanego do podścielenia protezy pooperacyjnej oraz wynik leczenia protetycznego.

Wyniki. U pacjentów zdiagnozowano 25 nowotworów szczęki, 8 żuchwy i 2 torbiele szczęki. Wykonano 41 pooperacyjnych uzupełnień protetycznych. W 16 przypadkach zdiagnozowano raka płaskonabłonkowego. Najwięcej pacjentów pochodziło z Wrocławia (13 osób). Ocenę wyników leczenia przeprowadzono na podstawie wywiadu i badania klinicznego pacjenta.

Wnioski. 1) Najliczniejszą grupę pacjentów stanowią osoby starsze, w wieku 61-70 lat, bez istotnej różnicy jeśli chodzi o podział uwzględniający płeć. 2) Przyczyną powodującą konieczność leczenia chirurgicznego częściej są nowotwory szczęki niż żuchwy. 3) Wśród rozpoznań histopatologicznych znacząco dominuje rak płaskonabłonkowy, inne rodzaje nowotworów występują rzadziej. 4) Najczęściej wykonywanym pooperacyjnym uzupełnieniem protetycznym są płytki obturujące. 5) Analiza danych dotyczących zawodu wykonywanego przez osoby operowane z powodu nowotworów szczęki lub żuchwy pozwala przypuszczać, iż istotnym czynnikiem etiopatogenetycznym może być kontakt ze środkami chemicznymi.
\end{abstract}

Słowa kluczowe: płytka obturująca, protezy pooperacyjne, tworzywo termoplastyczne.

\begin{abstract}
Introduction. The aim of prosthetic treatment after surgery in the region of the jaws is to obtain restoration of occlusion, restoration of the chewing function, speech improvement, better appearance of the patient, as well as sealing the operated area.

Aim. The objective of the study was to analyse upper and lower jaw postoperative prosthesis in a group of patients treated in the years 2002-2015 in the Dental Prosthetics Clinic at the Medical University in Wroclaw.

Material and methods. Research material consisted of 35 patients (17 women and 18 men) aged from 24 to 91 years. The patients were divided according to age, gender, reason for surgery and diagnosis, number and type of prostheses, place of residence, profession, type of soft material used for relining dentures, and treatment results.

Results. 25 patients were diagnosed with cancer of the maxilla, 8 patients were diagnosed with cancer of the mandible, and 2 patients were diagnosed with maxilla cysts. There were 41 postsurgical prostheses made. In 16 cases, most of which were patients from Wroclaw, squamous cell carcinoma was diagnosed. Evaluation of the results of treatment was based on the patients' history and clinical examination.

Conclusions. 1) The largest group of patients were the elderly, aged 61-70 years, with no significant difference by gender. 2) The factor causing the need for surgical treatment was more likely maxillary cancer than mandibular cancer. 3) Squamous cell carcinoma was the most frequent histopathological diagnosis, other types of cancer being less common. 4) Obdurate plates were used most often as post-operative prostheses. 5) After analysing the data relating to the professions performed by the people operated on for cancer of the maxilla or mandible, it can be assumed that the most important etiopathogenic factor may be contact with chemicals.
\end{abstract}

Keywords: obdurate plate, post-surgical prostheses, thermoplastic resin.

\section{Wstęp}

Leczenie protetyczne po zabiegach operacyjnych w zakresie szczęki i żuchwy ma za zadanie odtwo- rzyć okluzję, przywrócić funkcję żucia, poprawić mowę oraz wygląd zewnętrzny pacjenta [1]. 
W przypadku resekcji szczęki istnieje potrzeba zamknięcia połączenia między jamą ustną a jamą nosową [2-6]. Korzystny wynik leczenia protetycznego uzyskujemy poprzez stabilizację płytki obturującej i protez pooperacyjnych [7-11] oraz uszczelnienie i odciążenie obrzeża operowanego, stosując miękkie elastomery do podścielania protez [12-17].

\section{Cel}

Celem pracy jest analiza wykonanych protez pooperacyjnych szczęki i żuchwy w latach 20022015 w Zakładzie Protetyki Stomatologicznej Uniwersytetu Medycznego im. Piastów Śląskich we Wrocławiu.

\section{Materiał i metody}

Podstawą do badań byli pacjenci leczeni protetycznie po zabiegach operacyjnych w zakresie szczęki i żuchwy. Pacjenci byli leczeni chirurgicznie w Klinice Chirurgii Szczękowo-Twarzowej, Zakładzie Chirurgii Stomatologicznej Uniwersytetu Medycznego im. Piastów Śląskich we Wrocławiu oraz w Szpitalu Wojskowym we Wrocławiu, natomiast protetycznie w Zakładzie Protetyki Stomatologicznej Uniwersytetu Medycznego im. Piastów Śląskich we Wrocławiu. Ogółem do leczenia protetycznego przyjęto 35 pacjentów, w tym 17 kobiet i 18 mężczyzn.

Wiek leczonych pacjentów wahał się między 24 a 91 lat, przy czym kobiety były w wieku od 34 do 85 lat, a mężczyźni w wieku od 24 do 91 lat. $Z$ analizy wynika, że najwięcej pacjentów odnotowano w wieku 61-70 lat (13 osób), mniej w wieku 71-80 lat (7 osób), a w przedziałach wiekowych od 31 do 40 lat, od 51 do 60 lat oraz od 81 do 90 lat były leczone po 4 osoby. W innych grupach wiekowych były to pojedyncze osoby (Tabela 1).

U pacjentów zdiagnozowano 25 nowotworów szczęki, 8 nowotworów żuchwy i 2 torbiele szczęki (Tabela 2). W 16 przypadkach rozpoznanie histopatologiczne wskazało raka płaskonabłonkowego. W pozostałych przypadkach rozpoznano u 3 pacjentów guz szczęki, u 2 gruczolakorak i u 2 torbiel szczęki, w pojedynczych przypadkach był to włókniak szczęki, guz olbrzymiokomórkowy, rak podstawno-komórkowy, guz dziąsła, zwłóknienie szpiku kostnego, włókniako-mięsak, nowotwór złośliwy podniebienia, rak dna jamy ustnej, rak masywu szczękowo-sitowego, rak dziąsła, mięsak szczęki i rak gruczołowo-torbielowaty (Tabela 3 ).

W sumie protetycznie u pacjentów wykonano 41 uzupełnień pooperacyjnych, w tym 10 protez całkowitych szczęki, 6 protez całkowitych żuchwy, 5 protez częściowych szczęki, 2 protezy częściowe żuchwy, 2 małe obturatory, 14 płytek obturujących i 2 protezy twarzy (Tabela 4).

Spośród pacjentów leczonych chirurgiczno-protetycznie 13 osób mieszkało we Wrocławiu, a 2 osoby w Legnicy. Natomiast $z$ innych miejscowości (Otmuchowa, Przemowa, Szczegowa, Polkowic, Wołowa, Bornego Sulinowa, Nowej Soli, Kępna, Piechowic, Nowego Kościoła, Chojnowa, Ruszowa, Brzegu, Głogowa, Wołczynu, Bolesławca, Lewkowa, Kamieńca Wrocławskiego, Oławy i Przemkowa) odnotowano po 1 pacjencie (Tabela 5).

Pacjenci wykonywali następujące zawody: rolnik (2), elektromechanik (1), elektryk (1), siostra zakonna (1), kuśnierz (1), uczeń (1), ekonomista (1), zdobnik szkła (1), technik mechanik (1), ślusarz (1). Rencistów było 3, emerytów 9. Należy zaznaczyć, że 12 pacjentów nie chciało podać wykonywanego przez siebie zawodu (Tabela 6).

Podścielono 39 protez pooperacyjnych. W tym celu stosowano następujące materiały: Ufi Gel SC firmy VoCo (Niemcy), Mucopren soft - Kettenbach (Niemcy), Mega Base - Dreve (Niemcy), GC Reline Extra Soft - GC Corporation (Japonia), Elite soft relining - Zhermack (Włochy). Materiałem Ufi Gel SC podścielono 16 protez pooperacyjnych, Mucopren soft 7 protez, Mega Base 4 protezy, GC Reline Extra Soft 6 protez i Elite soft relining 6 protez (Tabela 7).

Ocenę wyników leczenia przeprowadzono na podstawie wywiadu i badania klinicznego pacjentów, których podzielono na dwie grupy ze względu

Tabela 1. Podział pacjentów ze względu na wiek i płeć

Table 1. Patients according to age and gender

\begin{tabular}{|l|c|c|c|c|c|c|c|c|}
\hline \multicolumn{1}{|c|}{ Płeć Wiek } & $21-30$ lat & $31-40$ lat & $41-50$ lat & $51-60$ lat & $61-70$ lat & 71-80 lat & $81-90$ lat & Powyżej 90 lat \\
\hline Kobiety & - & 2 & 1 & 2 & 7 & 2 & 3 & - \\
\hline Mężczyźni & 1 & 2 & - & 2 & 6 & 5 & 1 & 1 \\
\hline Razem & 1 & 4 & 1 & 4 & 13 & 7 & 4 & 1 \\
\hline
\end{tabular}

Tabela 2. Przyczyny wpływające na wykonanie zabiegu operacyjnego

Table 2. Reasons for surgery

\begin{tabular}{|l|c|c|c|c|}
\hline Zdiagnozowano & Nowotwór szczęki & Nowotwór żuchwy & Torbiel szczęki & Razem \\
\hline Liczba & 25 & 8 & 2 & 35 \\
\hline
\end{tabular}


Tabela 3. Rozpoznanie

Table 3. Diagnosis

\begin{tabular}{|l|c|}
\hline \multicolumn{1}{|c|}{ Rozpoznanie } & llość osób leczonych \\
\hline Rak płaskonabłonkowy & 16 \\
\hline Włókniak szczęki & 1 \\
\hline Gruczolakorak & 2 \\
\hline Guz olbrzymio komórkowy & 1 \\
\hline Rak podstawno komórkowy & 1 \\
\hline Guz dziąsła & 1 \\
\hline Zwłóknienie szpiku kostnego & 1 \\
\hline Włókniako-mięsak & 1 \\
\hline Nowotwór złośliwy podniebienia & 1 \\
\hline Rak dna jamy ustnej & 1 \\
\hline Rak masywu szczękowo-sitowego & 1 \\
\hline Rak dziąsła & 1 \\
\hline Guz szczęki & 3 \\
\hline Mięsak szczęki & 1 \\
\hline Rak gruczołowo torbielowaty & 1 \\
\hline Torbiel szczęki & 2 \\
\hline Razem & 35 \\
\hline
\end{tabular}

Tabela 4. Liczba i rodzaj wykonanych protez pooperacyjnych ruchomych

Table 4. Number and type of postoperative removable dentures

\begin{tabular}{|c|c|c|c|c|c|c|c|c|}
\hline $\begin{array}{c}\text { Rodzaj protez } \\
\text { pooperacyjnych }\end{array}$ & $\begin{array}{c}\text { Protezy } \\
\text { całkowite } \\
\text { szczęki }\end{array}$ & $\begin{array}{c}\text { Protezy } \\
\text { całkowite } \\
\text { żuchwy }\end{array}$ & $\begin{array}{c}\text { Protezy } \\
\text { częściowe } \\
\text { szczęki }\end{array}$ & $\begin{array}{c}\text { Protezy } \\
\text { częściowe } \\
\text { żuchwy }\end{array}$ & $\begin{array}{c}\text { Małe } \\
\text { obturatory }\end{array}$ & $\begin{array}{c}\text { Płytki } \\
\text { obturujące }\end{array}$ & Epitezy & Razem \\
\hline $\begin{array}{c}\text { Liczba wykonanych } \\
\text { prac protetycznych }\end{array}$ & 10 & 6 & 5 & 2 & 2 & 14 & 2 & 41 \\
\hline
\end{tabular}

Tabela 5. Miejsce zamieszkania leczonych pacjentów

Table 5. Patients' place of residence

\begin{tabular}{|l|c|}
\hline \multicolumn{1}{|c|}{ Miejsce zamieszkania } & Ilość osób leczonych \\
\hline Wrocław & 13 \\
\hline Legnica & 2 \\
\hline Otmuchów & 1 \\
\hline Przemów & 1 \\
\hline Strzegów & 1 \\
\hline Polkowice & 1 \\
\hline Wołów & 1 \\
\hline Borne Sulinowo & 1 \\
\hline Nowa Sól & 1 \\
\hline Kępno & 1 \\
\hline Piechowice & 1 \\
\hline Nowy Kościół & 1 \\
\hline Chojnów & 1 \\
\hline Ruszów & 1 \\
\hline Brzeg & 1 \\
\hline Głogów & 1 \\
\hline Wołczyn & 1 \\
\hline Bolesławiec & 1 \\
\hline Lewków & 1 \\
\hline Kamieniec Wrocławski & 1 \\
\hline Oława & 1 \\
\hline Przemków & 1 \\
\hline Razem & 35 \\
\hline
\end{tabular}


Tabela 6. Zawód wykonywany przez pacjenta

Table 6. Patients' occupation

\begin{tabular}{|l|c|}
\hline \multicolumn{1}{|c|}{ Zawód } & llość osób leczonych \\
\hline Rolnik & 2 \\
\hline Elektromechanik & 1 \\
\hline Elektryk & 1 \\
\hline Siostra zakonna & 1 \\
\hline Kuśnierz & 1 \\
\hline Uczeń & 1 \\
\hline Ekonomista & 1 \\
\hline Zdobnik szkła & 1 \\
\hline Technik mechanik & 1 \\
\hline Ślusarz & 1 \\
\hline Rencista & 3 \\
\hline Emeryt & 9 \\
\hline Nie podaje & 12 \\
\hline Razem & 35 \\
\hline
\end{tabular}

Tabela 7. Rodzaj materiałów miękkich i liczba wykonanych podścieleń protez pooperacyjnych

Table 7. Type of soft material and number of postoperative relinings

\begin{tabular}{|l|c|c|c|c|c|}
\hline \multirow{2}{*}{} & \multicolumn{5}{|c|}{ Rodzaj materiału miękkiego użytego do podścieleń } \\
\cline { 2 - 6 } & $\begin{array}{c}\text { Ufi Gel SC } \\
- \text { VoCo } \\
\text { Niemcy }\end{array}$ & $\begin{array}{c}\text { Mucopren soft } \\
\text { - Kettenbach } \\
\text { Niemcy }\end{array}$ & $\begin{array}{c}\text { Mega Base } \\
\text { - Dreve } \\
\text { Niemcy }\end{array}$ & $\begin{array}{c}\text { GC Reline Extra Soft } \\
- \text { GC Corporation } \\
\text { Japonia }\end{array}$ & $\begin{array}{c}\text { Elite soft relining } \\
\text { - Zhermack } \\
\text { Włochy }\end{array}$ \\
\hline Liczba podścieleń & 16 & 7 & 4 & 6 & 6 \\
\hline Razem & \multicolumn{5}{|c|}{39} \\
\hline
\end{tabular}

Tabela 8. Wynik leczenia protetycznego pacjentów

Table 8. Treatment outcome evaluation

\begin{tabular}{|l|c|c|}
\hline Wynik leczenia protetycznego & Bardzo dobry & Dobry \\
\hline Liczba pacjentów & 12 & 23 \\
\hline$\%$ & $34,28 \%$ & $65,72 \%$ \\
\hline
\end{tabular}

na wynik leczenia. Pod uwage brano następujące parametry: odtworzenie okluzji, przywrócenie funkcji żucia, poprawę wymowy, czas adaptacji protez oraz wygląd zewnętrzny pacjenta. Bardzo dobry wynik leczenia uzyskano u 12 pacjentów tj. 34,28\%, natomiast dobry u 23 pacjentów tj. $65,72 \%$ (Tabela 8).

W znaczącej części przypadków leczenie odbyło się jednoetapowo, a w pozostałej dwuetapowo. Leczenie dwuetapowe odbywało się wtedy, kiedy pacjent po zabiegu operacyjnym trafiał do leczenia protetycznego bez wstępnego zaopatrzenia protetycznego. Leczenie dwuetapowe zazwyczaj wiązało się z wykonaniem płytki obturującej, a następnie protezy ostatecznej. Płytkę obturującą wykonywano po zabiegu na okres przejściowy, w celu utrzymania tkanek miękkich w stałym położeniu przestrzennym i zamknięcia połączenia między jamą ustną a jamą nosową.

Należy podkreślić, że tak w płytce obturującej jak i w protezie ostatecznej miejsca kontaktu z raną pooperacyjną były uszczelnione i odciążo- ne za pomocą miękkiego elastomeru silikonowego. Materiał miękki był połączony z twardą płytą protezy za pomocą kleju firmowego i ukształtowany czynnościowo. Za bardzo dobry wynik leczenia protetycznego uznano uzyskanie u pacjentów stabilizacji płytki obturującej lub protezy pooperacyjnej, zamknięcie połączenia między jamą ustną a nosową, odtworzenie okluzji oraz przywrócenie funkcji żucia i mowy. Bardzo istotnym elementem leczenia jest poprawa wyglądu zewnętrznego pacjenta oraz jego zadowolenie z wyników leczenia. Do grupy z dobrym wynikiem leczenia kwalifikowano pacjentów zadowolonych z leczenia, u których jednak badaniem klinicznym stwierdzano słabszą stabilizację protezy pooperacyjnej.

Należy podkreślić, że wszystkie miękkie elastomery silikonowe stosowane do podścielenia przyklejano do płyt protez, co nie powodowało ujemnego oddziaływania na podłoże śluzówkowo-kostne, a zastosowane materiały miękkie nie traciły swej elastyczności w jamie ustnej. Należy podkreślić, że podczas użytkowania protez w za- 
leżności od potrzeby można było materiały miękkie wymieniać co pewien okres czasu.

\section{Wnioski}

Na podstawie uzyskanych badań stwierdzono:

1. Najliczniejszą grupę pacjentów stanowią osoby starsze, w wieku 61-70 lat, bez istotnej różnicy jeśli chodzi o podział uwzględniający płeć.

2. Przyczyną powodującą konieczność leczenia chirurgicznego częściej są nowotwory szczęki niż żuchwy.

3. Wśród rozpoznań histopatologicznych znacząco dominuje rak płaskonabłonkowy, inne rodzaje nowotworów występują rzadziej.

4. Najczęściej wykonywanym pooperacyjnym uzupełnieniem protetycznym są płytki obturujące.

5. Analiza danych dotyczących zawodu wykonywanego przez osoby operowane z powodu nowotworów szczęki lub żuchwy pozwala przypuszczać, iż istotnym czynnikiem etiopatogenetycznym może być kontakt pacjenta ze środkami chemicznymi.

\section{Oświadczenia}

Oświadczenie dotyczące konfliktu interesów

Autorzy deklarują brak konfliktu interesów w autorstwie oraz publikacji pracy.

\section{Źródła finansowania}

Autorzy deklarują brak źródeł finansowania.

\section{Piśmiennictwo}

[1] Rolski D. Wpływ leczenia uzupełniającego na jakość życia pacjentów po leczeniu nowotworów części twarzowej czaszki. Protet Stomatol. 2013;LXIII(5):405-413.

[2] Singh M, Bhushan A, Kumar N, Chand S, Obturator prosthesis for hemimaxillectomy patients. Natl J Maxillofac Surg. 2013;4(1):117-120.

[3] Shrestha B, Hughes ER, Kumar M, Singh R, Suwal P, Parajuli PK, Shrestha P, Sharma A, Adhikari G. Fabrication of Closed Hollow Bulb Obturator Using Thermoplastic Resin Material. Case Rep Dent. 2015;2015:504561.

[4] Choudhury M, Shanmuganathan N, Padmanabhan TV, Swarup S, Grover M, Arumugam M. Rehabilitation of Post Surgical Maxillectomy Defects Using Interim Obturators - A Case Series. Indian J Surg Oncol. 2014;5(4):315320.

[5] Nieborak R, Rolski D, Mierzwińska-Nastalska E. Nowa koncepcja pooperacyjnej protezy składanej stosowanej w rehabilitacji pacjentów po resekcji szczęki. Protet Stomatol. 2014;LXIV(2):97-101.
[6] Nieborak R, Rolski D, Mierzwińska-Nastalska E, Zastosowanie termoformowalnego obturatora łaczonego $z$ protezą szkieletową u pacjenta po resekcji szczęki - opis przypadku. Protet Stomatol. 2014;LXIV(4):286-291.

[7] Karthikeyan S, Balu K, Devaki V, Ajay R, A simple method of enhancing retention in interim hollow bulb obturator in a case of an acquired palatal defect, J. Pharm Bioallied Sci. 2015;7(Suppl. 2):S782-S785.

[8] Soni R, Jindal S, Singh BP, Mittal N, Chaturvedi TP, Prithviraj DR. Oral rehabilitation of a patient with sub - total maxillectomy. Contemp Clin Dent. 2011;2(1):63-65. doi: 10.4103/0976-237X.79293.

[9] Kar AK, Parkash H, Garhnayak L, Chittaranjan B, Fabricating a Hollow Obturator with Light-Cured Resin System, J Indian Prosthodont Soc. 2013;13(3):348-351.

[10] Shambharkar VI, Puri SB, Patil PG. A simple technique to fabricate a surgical obturator restoring the defect in original anatomical form. J Adv Prosthodont. 2011;3(2):106109. http://dx.doi.org/10.4047/jap.2011.3.2.106.

[11] Kasperski J, Rosak P. Rehabilitacja protetyczna po zabiegu resekcji szczęki - opis przypadku. Protet Stomatol. 2008;:LVIII(2):124-129.

[12] Manikanatan NS, Balakrishnan D, Hollowbulb Obturator with Cast Retainers: A Case Report. J Int Oral Health. 2013;5(5):116-119.

[13] Rolski D, Nieborak R, Śmiga-Witas A, Starościak S, Dolegacz-Bączkowska A. Rehabilitacja protetyczna po zabiegu resekcji szczęki - opis przypadku. Protet Stomatol. 2006;LVI(6):450-455.

[14] Rolski D, Nieborak R, Mierzwińska-Nastalska E. Rehabilitacja protetyczna pacjentów po zabiegach chirurgicznych z powodu nowotworów szczęki - opis przypadków. Czas Stomatol. 2007; LX(5):330-338.

[15] Nieborak R, Rolski D, Mierzwińska-Nastalska E. Kostrzewa-Janicka J, Starościak S, Rehabilitacja protetyczna pacjentów z ubytkami podniebienia miękkiego po operacjach nowotworów części twarzowej czaszki - opis przypadków. Protet Stomatol. 2010;LX(1):50-54.

[16] Kucharski Z, Rolski D. Zastosowanie kliniczne materiałów elastycznych do podścieleń ruchomych uzupełnień protetycznych. Protet Stomatol. 2011;LXI(3):234-240.

[17] Kucharski Z, Dominiak K. Zastosowanie materiałów elastycznych w leczeniu protetycznym bezzębia u pacjenta po zabiegu osteosyntezy trzonu żuchwy - opis przypadku. Protet Stomatol. 2013;LXIII(2):134-139.

Zaakceptowano do edycji: 2016-04-28 Zaakceptowano do publikacji: 2016-05-06

\section{Adres do korespondencji:}

Joanna Smardz

Katedra Protetyki Stomatologicznej

Uniwersytet Medyczny we Wrocławiu

ul. Krakowska 26, 50-425 Wrocław

tel.: 661825441

e-mail: joanna.smardz@umed.wroc.pl 